\title{
'All You Need is Love': Some Thoughts on the Structure, Texture, and Meaning of the Brothers Song as well as on Its Relation to the Kypris Song (P. Sapph. Obbink)
}

\author{
Anton Bierl
}

More than two years have passed since we first heard in January 2014 of the spectacular new discovery of two completely new poems from an Alexandrian edition of Sappho's famous first book. Mere months after the discovery, Burris, Fish, and Obbink (2014) published four additional papyrus fragments providing new readings at the margin of several Sapphic fragments $(5,9,16,17)$, that together with other tiny parts-ended up in the Green Collection (GC) in Oklahoma (inv. 105).

These pieces come from the larger cartonnage enveloping the main fragment that gave us these two hitherto unknown texts: the 'Brothers Song' and the 'Kypris Song' of the London P. Sapph. Obbink-Obbink (2014b) produced the editio princeps alone in the same issue no. 189 of $Z P E$.

It goes without saying that reconstructing Sappho, her context, and her specific role in Lesbian society as well as the meaning of Sapphic love dominates the consideration of her work. In recent years research on Sappho has devolved into an ideological minefield, a hotly debated battleground. In a feminist vein, Parker (1993) challenged the communis opinio dominating scholarship on Sappho, namely that the poet headed a circle of young adolescent girls — read: not coeval women - in a sort of educational or "initiatory" group or choros led by the choregos, i.e. the much older, more experienced Sappho. ${ }^{1}$ According to the

1 On Sappho generally as a chorus leader, see Calame (1977) 127, 369-370 (in English, Calame [2001/1997] 65, 212); Ferrari (2010) 33-37; on an originally choral performance of Sappho in general see Nagy (1990a) 370, (1993), (2007a), (2007b) 211-212, 215-216, 26o and in this volume; Lardinois (1994) and (1996); see also Bierl (2003), (2008), (2016). On the chorus as the social context of initiation, see Calame (1977) 385-420 (in English, Calame [2001/1997] 221-244) and Bierl (2001) (in English, Bierl [2009]) Index s.v. 'Erziehung' and ' $\pi \alpha \iota \delta \varepsilon \iota^{\alpha}$ '. See also Ferrari (2010) 34. On the parallel of initiation in general, see Calame (1977) 367-372, 390-391, 400-404, 427432, 437-438 (in English, Calame [2001/1997] 210-214, 225, 231-233, 249-252, 256-257) and

(C) ANTON BIERL, 2016 | DOI: 10.1163/9789004314832_016

This is an open access chapter distributed under the terms of the Creative Commons Attribution- 
traditional view, Sappho introduced these young girls to the values of beauty in an all-encompassing and synesthetic manner. The practices-connected somehow to a cultic service to Aphrodite-aimed to familiarize them with myths, music, dance, songs, and beauty-centered ( $\kappa \dot{\alpha} \lambda$ ㅇs) content in order to foster awareness of their own beauty and make them more desirable for future matrimony. This religiously charged life appealed to all the senses, enhanced by erotic tensions both among the young girls themselves and between the group and Sappho. Anthropological parallels in a cross-cultural comparison help explain, in a broad sense, ${ }^{2}$ this archaic form of education that prepared aristocratic adolescents for marriage. The temporary seclusion ends with the telos of marriage.

Holt Parker, Eva Stehle, and most recently Renate Schlesier, however, have attempted to demonstrate that the circle consisted of coeval women. ${ }^{3}$ For Schlesier in particular they are not just friends and therefore analogous to the male political companions (hetairoi) in the aristocratic factions (heteireiai), but hetairai in the sense of well-educated and seductive courtesans such as appeared in the Athenian symposia of the 5 th and 4 th centuries BC. On the basis of their names, their emphasis on female beauty, luxury, musical skill, and erotic appeal as well as their apparent anchoring in the symposium, Schlesier claims that the intended performers of Sappho's poetry and her companions were real hetairai. ${ }^{4}$ At times one could even think that Schlesier argues that Sappho herself is a hetaira. This new interpretation tempts some critics today as it renders Sappho "more female"-less problematic and "Other." But do we not then fall prey to the later Sapphic reception begun with Old Comedy and extending through Hellenistic times to Athenaeus, when the specific occasion and otherness of Sapphic love in her circle could no longer be understood? This view tends to downplay all evidence of an age hierarchy-in fragments and testimonies we often find the address paides for the female and beloved friends. ${ }^{5}$ Moreover it ignores the homoerotic tension between an older Sappho and members of the circle — or even among the group — that we encounter in some of the poems, which fits Sappho into a wider anthropological model of a choral transmission of values. Above all, in an archaic aristocratic society like

(1999a); especially for Sappho, see Calame (1977) 400-404 (in English, Calame [2001/1997] 231-233) and Ingalls (2000) 12-14.

2 Lardinois (2010) has in fact, for what it is worth, challenged these anthropological parallels.

3 Parker (1993); Stehle (1997) 262-318; and most recently Schlesier (2013) and (2014a).

4 On a similar stance, see also Bowie in this volume.

5 For a list of evidence, see Lardinois (1994) esp. 58-70 and Ferrari (2010) 34-37; for paides and parthenoi, see Calame (2013b). 
the one in Lesbos it would be highly improbable that a woman of high birth like Sappho composed poetry to be performed by courtesans, as doing so would run counter to the aristocratic code Sappho idealistically represents in her poems.

This new feminist and deconstructive approach fuses the distinction between the original socio-historical context, in which Sappho and her circle performed the songs at Mytilene in Lesbos around 6оо вс, and later Sapphic receptions. ${ }^{6}$ The image of Sappho as a hetaira obsessed with heterosexual love slots in nicely with the generic distortion of Old Comedy, which notoriously associates her with courtesans. Indeed, it can already be dated back to the point when Sapphic poetry entered Attic symposia at the end of the sixth century BC. ${ }^{7}$

Herodotus' narrative about Charaxos' interactions with a prostitute in the nouveau-riche milieu of Naucratis (2.134-135) may constitute one of the first steps in influencing Sappho's image and her reception. ${ }^{8}$ However, although possessing rather limited knowledge of Lesbos between $620-580$ вС in comparison to classical Athens, we must attempt to elucidate and reconstruct as adequately as possible the socio-historical circumstances of the primary recipient and the Sitz im Leben of Sappho's Lesbian performances. Sappho marks a particularly interesting case of a diachronic development in which her image is constantly reshaped. ${ }^{9}$ For many Sapphic songs we can suppose a choral and ritual performance at the Pan-Lesbian sanctuary at Messon. ${ }^{10}$ The mythic-ritual complex interacts with the scripted performance of young girls at the threshold to adulthood or other women assembled in order to sing and dance for the gods. Songs about love and beauty are essential for transmitting value concepts, an education in the broadest sense. ${ }^{11}$ Sappho composed for various occasions and various audiences made up of a rather traditional society deeply involved in aristocratic-elitist networks of rivaling clans. ${ }^{12}$ It is certainly possible that

$6 \quad$ Generally against the neo-liberal and feminist approach, see Calame (1998); Gentili and Catenacci (2007). A refutation of Parker (1993) is Lardinois (1994); see also Aloni (1997) xlviii.

7 See Yatromanolakis (2007).

8 See Obbink $(2014 b) 3^{2}$.

9 See Yatromanolakis (2007); Nagy (2007b); Acosta-Hughes (2010); Bierl (2010); and Nagy in this volume.

10 Nagy (1993), (2007a), (2007b); for fr. 17 see Nagy and Caciagli in this volume; on the sanctuary at Mesa, the modern Greek equivalent to ancient Messon, see Robert (196ob); Pfrommer (1986); Caciagli (2010). For its location, see Fig. 8.1, p. 199.

11 Bierl (2003), (2008), (2010).

12 See Aloni (1997) xlvi-lxxxii, esp. his division into three groups (lviii): 1) marriage songs, 
already during her lifetime certain songs were reperformed in different venues such as the aristocratic symposium. After all, the general reflection inherent in Sapphic poetry can be readily transposed to new occasions where even male audiences will appreciate its beauty. Thus both reperformance and the shift from primary to secondary reception that goes hand in hand with the detachment from Lesbos to new centers of political and cultural importance, particularly Athens, in the ensuing centuries, are key factors in her diachronic development. Moreover, the secondary reception of Sappho found new occasions and audiences in the male symposium and festivals like the Panathenaia in Athens, where Sappho had a rich Nachleben. ${ }^{13}$

In terms of methodology, attempts to reconstruct the original performance situation have shifted paradigmatically from biographic to pragmatic approaches. ${ }^{14}$ However, our interpretations of the new texts show that we are still tempted to read the texts as family history. For example a rather literal interpretation of the new Brothers Song seems to document a conversation between Sappho and her mother about the absent brother Charaxos, a conversation touching on his chances of a safe return, the fortune of the family, and a possible relief from anguish via the younger brother Larichos. ${ }^{15}$ Pragmatically, we have to address the Sitz im Leben, the original occasion for the song's performance. We must reconstruct the socio-political, cultural, and anthropological setting to elucidate the poem's possible message and meaning. If we assume a public, choric, and ritual setting - we can envision a variety of flexible occasions, performances, and audience constellations - it hardly makes sense that Sappho sings biographically about the actual situation of her own family. But one could imagine Sappho in this manner, perhaps singing at a family gathering, in a later symposiastic reperformance. However, for the larger performance at a Lesbian festival, where originally the framing inscribed itself in the poetics of the text, it seems more likely that these familial stories were understood generally, family members as fictional personae with whom it was 'good to think.'16 The pri-

addressed to the entire polis; 2) songs regarding the female life, and poems reflecting the political life addressed to a female or male audience, that is a solitary group based on family or sociopolitical bonds; 3) songs dealing with the homoerotic and ritualistic relations in the Sapphic circle, addressed to the members of the circle.

This can be well demonstrated with regard to the Cologne Sappho; see e.g. Nagy (2009c); Lardinois (2009); Bierl (2010). More generally, see Nagy (2007b); Bierl (2010); and Nagy in this volume.

14 See e.g. Bierl (2003) and the literature cited ibid. n. 29.

15 See e.g. West (2014) and Ferrari (2014).

16 See e.g. Bierl (2003) 113-114 with n. 82; Nagy (2007b); on the fictional 'I', see also Calame 
vate experience that may have some anchoring in real life will be performed as a communalized and public experience with a pragmatic goal: educating the choral circle of younger girls in the values of beauty, ritual, and religious appropriateness, i.e. adequate gender-role behavior. In what follows I will argue that the Brothers Song like the Kypris Song deals with the vicissitudes of love and erotic suffering.

With the discovery of these new songs it becomes more and more evident that the first book of Sappho of the Alexandrian edition contained both family poems, especially ones about Charaxos, who, as we know from other sources, became enthralled in an erotic affair with a hetaira in Egypt, and poems reflecting upon the pathological state of erotic involvement more directly. We now detect the presence of a cycle of poems about Charaxos. But what is their point in the context of Sappho's poetry? A possible answer seems to be the experience of a private, 'sisterly affect', as Greg Nagy suggests in this volume, made public and communalized. Thus the Charaxos cycle publicly displays a female attitude and the very positive behavior of love for male family members in the context of the polis or the hetaireia. The dialogue about the consequences of a love affair from the sister's perspective sheds light on a personal constellation of love, but through a generic and public lens, thus foregrounding the repercussions on the fortune and economic situation of a leading aristocratic house. Everybody in the chorus and audience can identify with this story. Furthermore it details the appropriate religious and ritualistic handling of the situation -an all-encompassing education. And the sister-Greg Nagy explains "Sappho" as a pet name for 'sister' in this volume (esp. pp. 489-492) — might also be a special term for the relationships in a chorus. ${ }^{17}$ As choral leader she behaves like an older sister to her circle of adolescents; they are all emotionally connected as in a 'sorority', a society of female 'students' for social purposes, having homoerotic bonds between themselves and their 'sister'.

When we disregard less harmonious relationships like that between Electra and Chrysothemis in notoriously dysfunctional families, a sister is often considered an indisputable source of love, someone who is always there, a dear friend giving comfort and sharing experiences. Family relations are an ideal canvas onto which to project the complicated matters of the socio-political macrocosm, the polis or the larger aristocratic clan as well as those of smaller units like the chorus, also linked to political structures. Through the personal we can

(2005) $1-7$, (2009), and Boehringer and Calame in this volume. On the expression 'good to think with', see Lévi-Strauss (1962) 89 .

17 See the designation 'my cousin' ( $\tau \hat{\alpha} \varsigma \xi \xi \mu \hat{\alpha} \varsigma \alpha \hat{\alpha} v \varepsilon \psi \mid \hat{\alpha} \varsigma$ ) in Alcm. 1.52 for the chorus leader Hagesichora. 
address more public affairs metaphorically. It is well known that older sisters and brothers prove valuable guides in overcoming the crisis of adolescence. An older brother can also be a role model, a father substitute, or a source of great disappointment because, as he is older, he leads his own life, leaving the family behind, falling into erotic affairs, causing a sister to react with jealousy. On the other hand, the personal bond with a younger brother might be easier to maintain as the older sister takes on maternal functions in this constellation, projecting her hopes for a bright future onto him, as is case with Electra and Orestes.

If we look even closer, the Brothers Song treats the sensation of love at a deeper level. According to Herodotus, Charaxos has lost his heart in Egypt, spending his and the family's trade income on a hetaira. Although not explicitly mentioned in the Brothers Song (though identifying facts might have been mentioned in the missing part of the song), the poem seems to assume the audience is familiar with this background. Charaxos is so attached to DorichaRhodopis that his return seems rather improbable. Yet Larichos is still too young to take over the responsibilities of the clan. To a certain extent, Sappho transfers her hopes to the younger brother, though we know he serves as young wine-pourer (Sappho test. 203) and thus, in the mould of homoerotic male love, probably finds himself captured in the net of erotic affairs as well. Therefore the comfort Sappho takes in Larichos' existence seems precarious, at least for the moment. Perhaps the poem is an elegant and humorous play with something else in mind. From the external standpoint of a sister, Sappho takes this opportunity to comment on the sexual relations in her family and how they impact the group, presenting her brothers, like herself, and by extension the whole clan, as totally dedicated to love. In a symbolic, indirect, metaphorical, and quasi-mythic discourse she thus speaks about love in the Brothers Song as well.

In the Kypris Song, on the flip side, the speaking 'I', Sappho-perhaps with her choral group - details how love ravages her body_or their bodies. She analyzes herself now, her medical symptoms, and insists on her willingness to continue suffering. Love hurts, therefore she wishes for a respite Aphrodite will hardly grant. Sappho must endure all the terrible corporeal manifestations that make her more beautiful and more attractive as a lover. Above all, in a proto-philosophical manner she analyzes the experience of the pathos with full consciousness, understanding its consequences. The performance thus testifies to the drastic symptoms of this suffering for the sake of her chorus and the listeners.

Using both direct and indirect scenarios, Sappho and her group act out erotic sensations or reflections in order to become acquainted with the entanglements of love and prepare themselves for their female role in society, internalizing these values by singing and dancing. The wish for a procession and prayer 
to Hera as well as the words uttered in the Brothers Song constitute the actual first performance of these ritual practices at Messon; later on a female chorus can reperform the Brothers Song at the seasonally repeating festival. Sappho's family becomes a mythical foundation for new performances in mimesis of the original constellation establishing an eroticized discourse of love and absence. In short, the chorus members reenact Sappho and her poem of sisterly love and renew their bond of mutual affect.

\section{Linguistic and Poetic Structure of the Brothers Song}

I first provide the text with its structure in highlighted forms and markers: ${ }^{18}$

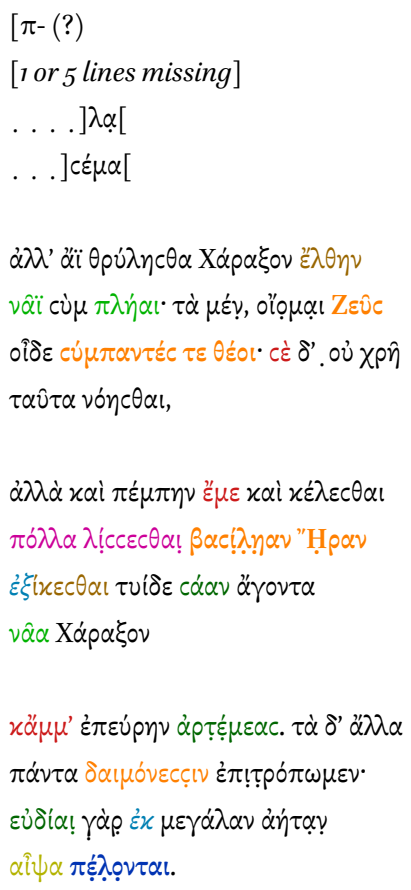

1

2

3

4

5

A: 'Charaxos returns'

a you chatter (direct statement): 'Charaxos comes' with ship full (wealth); I think Zeus ( $\mathrm{b}^{1 \mathrm{~m}}$ ) knows $\mathbf{b}$ and gods $\left(\mathbf{b}^{2}\right)$ : cascade of AcIs: from ov $\chi p \hat{\text { : }}$ 1 it is not right to think ${ }^{1}$ this (hybris)

(5) 10 b but ( $\dot{\alpha} \lambda \dot{\alpha})$ to send ${ }^{1} \mathrm{ME}$ (medium), summon ${ }^{2}$-> 2 to pray ${ }^{1}$ to Hera $\left(\mathbf{b}^{1 f}\right)->$ a 3 that Charaxos comes ${ }^{1}$ here with (part.) ship safe (indirect) finds ${ }^{2}$ us safe (enj.)// в: Our attitude: gnomic-general (10)

15 Gnome 1: argum. үỳ p sudden change (metabole) $\left(\mathbf{c}_{\mathbf{1}}\right)$ : out of storms comes fair weather-seafaring (love?)

18 The key to the highlighting colors in the Greek text is as follows: Orange: the gods and their positive effects on humans/blessedness; light green: ship; darker green: 'safe'; red: personal pronouns; pink: the central speech-act of prayer; blue: preposition or prefix $\dot{\varepsilon} x / \mathfrak{\varepsilon} \xi$ —'from

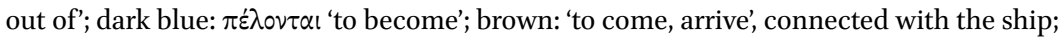
yellow: 'swift, sudden'. In the summary on the right side and in the translation below: Orange: the gods; green: 'safe' and reversals from negative to positive circumstances; brown: 'to come, arrive'; blue: preposition or prefix $\dot{\varepsilon} x / \dot{\xi} \xi$ - 'from out of'; yellow: 'swift, sudden'. 
$\tau \hat{\omega} \nu \varkappa \varepsilon \beta \dot{o} \lambda \lambda \eta \tau \alpha l \beta \alpha c i \lambda \varepsilon v e^{\prime} \mathrm{O} \lambda \dot{\mu} \mu \tau \omega$

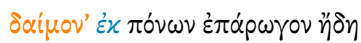

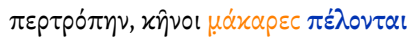

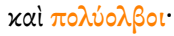

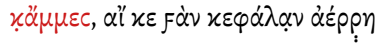

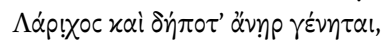

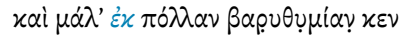

$\alpha i \psi \alpha \lambda \dot{\theta} \theta \varepsilon \mu \varepsilon v$. gen. rel. clause: of all, whomever Zeus $\left(b^{1 \mathrm{~m}}\right)$ wishes (Will of Zeus) $\mathbf{b}_{2}$-> helper-daimon $\left(\mathrm{b}^{2}\right)$ turn ek anguish

20 (metabole) $\left(\mathbf{c}_{2}\right) / /$

\section{c: And Larichos?}

WE: conditional clause: eventualis: if L. raises head and becomes a man: change of status $\left(\mathbf{c}_{\mathbf{3}}\right)$ from $(e k)$ anguish released:

(20) 24 sudden metabole $\left(\mathbf{c}_{\mathbf{4}}\right)$

$\mathrm{P}[\ldots$

$[\cdots$

... ] La[richos (?)

and] you, Mo[ther, should celebrate. (?)

5 But you are constantly chattering that CHARAXos (will) arrive with a full ship. That, I think, Zeus

knows and all the other gods. But you may not have

these things in mind,

(5) but you ought to send me and have me

10 pray much/imploringly to Queen Hera

that CHARAXos may come back here and bring

his ship safe,

(10) and find us safe and healthy. All other things

let us entrust to the gods/daimones:

15 for out of huge storms fair weather

abruptly ensues.

Of whomever the King of Olympus wishes

a god/daimon as helper to now turn them

(15) out of pains, those men are fortunate

$20 \quad$ and richly blessed.

And we, if LARICHOs raises his head

and finally one day becomes a man, would even from the many grievances of our soul

$24(20)$ be swiftly released. 
As our fragment begins with the adversative $\dot{\alpha} \lambda(\dot{\alpha})$, we know that at least one strophe precedes it. Due to an overlap with P. Oxy. 2289 fr. 5 , which provides the remnants of the last two lines of a Sapphic strophe $\left([\ldots] \lambda \alpha\left[/[\ldots] c \dot{\varepsilon}, \mu \alpha[\quad),{ }^{19}\right.\right.$ we can conjecture that the performing 'I' briefly introduces the situation in the missing part before our text begins. However, since Sappho sings about it over and over again, everybody already knows the story of Charaxos, who left Lesbos to trade in Naucratis in Egypt and became enthralled with Rhodopis-Doricha, a beautiful local prostitute. The story must have been well-known even before Sappho composed the Brothers Song. We are lucky that Herodotus (1.135), Strabo (17.1.33), and Athenaeus (13.596b-c) provide us with more background: Charaxos fell madly in love with Rhodopis-Doricha, paid a large sum to free her from servitude, and was about to spend his fortune made in wine trading on her. According to Herodotus, Charaxos did come home and Sappho rebuked him. But adopting the point of view of the 'I' and 'you' persons in the poem, Charaxos' return to Lesbos and by extension the situation of his family was in doubt because of this mad love affair. Will he really come back or will he be lost indefinitely in Egypt, the symbolic land of death and the Other, bound by the erotic fascination of a beautiful prostitute? The situation somewhat mirrors figures and scenes in the Odyssey: Odysseus captured by the sexually attractive Circe and Calypso; Menelaus lost in the rich land of Egypt; Telemachus, the model young man, surviving his rite de passage, a sea voyage. Their respective family members desperately wish for their return, but only the gods can help them traverse the sea and bring about their homecomings.

The performing 'I', most likely Sappho herself, breaks in with the $\alpha \lambda \lambda$ ' (5), a strong contrast, and addresses the 'always chattering' 'you'. The verb is quite derogatory, criticizing vain and idle behavior as well as the thoughtless affirmation of Charaxos imminent return. Without consideration of the gods the 'you' assures over and over again that Charaxos will 'return with a full ship' (5-6), i.e. securing the endangered fortune, freeing himself from the bonds of Doricha, and returning home without any problems. It is a purely secular and self-assuring position, something like: 'Don't worry—it'll be fine: you'll have your brother back safe, your family will be reunited, and, most of all, Charaxos, the potential male leader of the clan, will secure his economic foundation, accumulating wealth via trade and bringing it home. Upon his return he'll take over an important role in the political life of Lesbos'. In Sappho's (or the singing 'I's') eyes such assertions constitute vain chatter, an utterance full of hybris

19 See Obbink (2014b) 40 and West (2014) 9; see now also Obbink (2015a) 2, (2015b) 7, and chapter 2 in this volume. 
(arrogance), and an implausible option since it discounts the dangers of love and the sea, which threaten to destroy everything: Charaxos' life, his welfare, his return, the reunion with his family and friends, and, last but not least, the political existence of the hetaireia.

Let us go through the structure of the song in more detail:

A) The lyric 'I', i.e. Sappho as first person speaker and choragos of her choral group, opposes this superficial position and invokes Zeus and the gods. She carefully introduces her opposition through a parenthetical olopal (6) ('I think'), not wanting to offend the addressee, who possesses a certain authority - though the expression may also be intended ironically. But a strong indicative form contrasts the indirect expression of the homecoming (the accusative

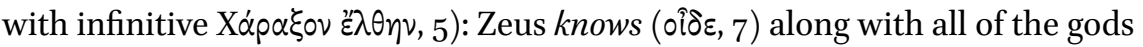
$(6-7)$. They have the power to know. It is the result of a cognitive process of seeing, thinking (see vónc $\theta \alpha \iota, 8$ ), realizing, and finally bringing Charaxos back home.

The first transmitted strophe then ends with an ethical command based on the impersonal o $\chi p \hat{\eta}$ (7)- 'it is not right'. The initial position of the 'you' in the accusative ( $\subset \dot{\varepsilon}, 7)$ puts the emphasis on the addressee and what the person should not do. The sentence initiates a cascade of infinitive and accusative with infinitive (AcI) constructions, which fill out the entire second strophe, and ends halfway through the first line of the third preserved strophe via enjambment. The prohibition 'it is not necessary that you think (vónc $\theta \alpha$ l) that' or 'it is forbidden for you to think that' (7-8) implies the 'you' has forgotten ethical standards and the gods, a violation of decency; in Sappho's analysis, postulating such an easy outcome without taking the gods into account constitutes a breach of dike (justice).

A positive command $(\dot{\alpha} \lambda \dot{\alpha}, 9)$ contrasts the negative prohibition again: but ( $\dot{\alpha} \lambda \lambda \dot{\alpha})$ you must send me and tell me' (9). Here we have a structure of growing elements, from one dependent verb to two. Now another accusative with infinitive construction depends on $\chi \dot{\varepsilon} \lambda \varepsilon c \theta \alpha$ : you command 'that I pray intensely to Queen Hera' (10) - the first person narrator clings to the main female goddess at Messon, addressing the divine with her royal title. Then a double accusative with infinitive ensues: Charaxos, in the last position of the second transmitted strophe (12), should come back here ( $\left.\tau v^{i} \delta \varepsilon, 11\right)$, to the here

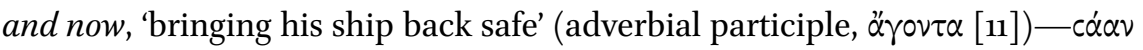

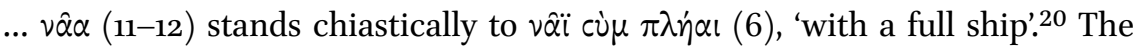

20 On the 'interweaved syntax $(A B A B)$ of the two nouns and their modifiers' regarding cá $\alpha \nu$ 
construction finally ends, falling into the third transmitted strophe: I should also pray to Hera 'that Charaxos will also find us' - 'us' now in the first emphatic

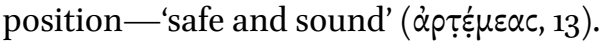

The following scheme visualizes the movement of thought:

1a. $\theta p \dot{\lambda} \lambda \eta c \theta \alpha \mathrm{l} X \alpha \dot{\alpha} \rho \alpha \xi o v \ddot{z} \lambda \theta \eta \nu$ (5) (AcI)

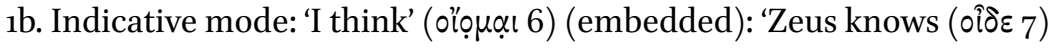
and all gods'.

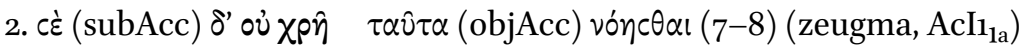

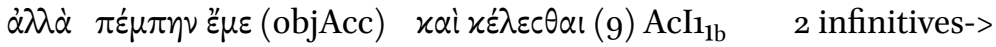

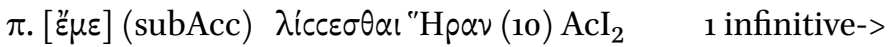

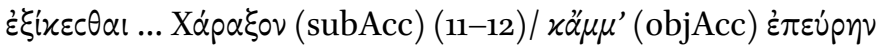

(13) $\mathrm{AcI}_{3}$

2 infinitives

The endings of the infinitives are $-\eta \nu$ (5) - $\eta c \theta \alpha l$ (8) - $\eta \nu$ (9) - $\varepsilon c \theta \alpha l$ (9) - $\varepsilon c \theta \alpha l$ (10) $\varepsilon c \theta \alpha \mathrm{l}$ (11) - $\eta \nu$ (13) and form a poetic pattern of rhyme based on homoeoteleuton in the following structure:

$$
a b a b_{1} b_{1} b_{1} a
$$

In terms of sequence and frequency we could describe the infinitives in part A as follows:

\section{i i ii i ii}

Moreover in the transmitted strophes 1 and 2 we have a slightly displaced mirror structure at their axis with a chiastic abba: Charaxos, lines 5 and 12; the ship, lines 6 and 11/12; the gods, lines 6/7 and 10 (abccba). In a parallel order, however, we have in the opening lines the authoritative order $x \varepsilon \dot{\varepsilon} \lambda \varepsilon c \theta \alpha$ l (9) instead of $\theta \rho \dot{ } \dot{\lambda}^{\prime} \eta \subset \theta \alpha$ (5). The mirror structure provides fusion and union, emphasizing Charaxos' return, the key motif, and providing two options. Additional stress is laid upon the notion of safety and salvation ( $\sigma \omega \tau \eta p i \alpha)$. Charaxos should return, bringing his ship safe (11), and he should find us sound and

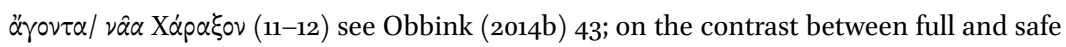
ship as the essence of the song, see Nünlist (2014). 
healthy (13). The 'I' now merges with the 'we', and the ensuing exhortative,

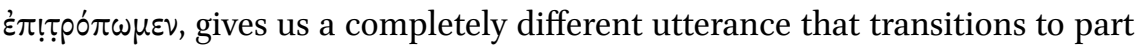
B.

в) With line $13 \mathrm{~b}$ a second part begins: transmitted strophes $3-4$. The thought proceeds directly from A. Instead of a chiastic $a b b a$-structure, we now have a three-step sequence: an exhortation and two gnomic statements $(a b b)$, thematically linked via parallel alternation (bıcıb2c2). The admonition, ह̇ $\pi ! \uparrow \rho o ́ \pi \omega \mu \varepsilon v$ (14), to entrust everything else to the gods/daimones (13-14) continues the reli-

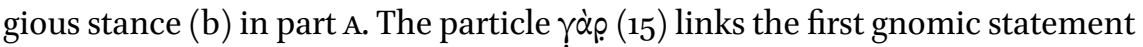
$\left(15^{-16)}\right.$, taken from nature and meteorology, with the exhortation and assertion of Zeus' and the gods' dominion over weather. The theme of an abrupt change or turn-around (metabole) is decisive (c): 'good weather quickly arises from big storms'. And the next general law concerning divine aid (b) and the bliss of those to whom they send a helper for support, indicates another change. Moreover this second gnomic statement harkens back to the initial exhortation and doubles its length to four lines, filling out the entire fourth stanza. The construction, a generalized relative clause with the relative pronoun in prolepsis as a partitive genitive and the verb in iterative form combined with $\chi \varepsilon$

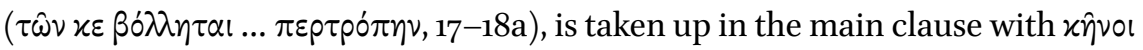
(19): 'Out of those, whomever ...' The use of the same preposition '̇ $x(15,18)$

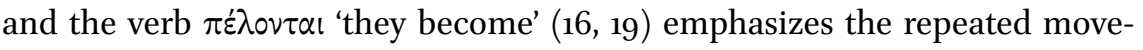
ment away from a bad situation to a good one. Somehow the metaphorical paradigm as image attaches to the more general religious certainty and both exemplary gnomic statements closely interact with the real dangers of seafaring.

West ([2014] 9), followed by Ferrari ([2014] 2-3), wants to emend line 18 [14],

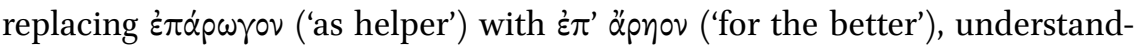

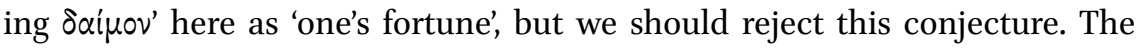
transmitted text appears to be more complex than this simplifying conjecture, but it is now identified by Albert Henrichs as a model for Theocritus' learned imitation in his hymn to Ptolemy II (Idyll 17.123-132). There we even find an allusion to the $\beta \alpha c^{\prime} \lambda \varepsilon v c^{\prime} \mathrm{O} \lambda \dot{v} \mu \pi \omega$ of line 17 [13] when Theocritus refers to Zeus

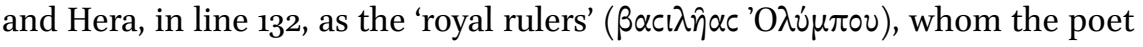
compares to Ptolemy I Soter and his wife Berenice. ${ }^{21}$ In the Orphic Hymn $74.8-9$

21 Henrichs (forthcoming) (not seen) cited in Obbink (2015b) 6: Theocritus praised the ruler: he built shrines dedicated to his mother and father (Ptolemy Soter) ... as 'helpers': $\mu \alpha \tau i$

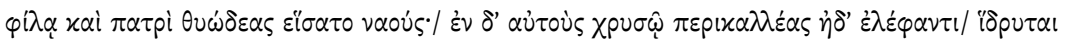


we encounter a fitting parallel for the use of an adverbial supplement 'as helper' ( $\dot{\pi} \pi \alpha \rho \omega \gamma o ́ \varsigma)$, also in a mystic context; ${ }^{22}$ Leucothea is summoned to aid people distressed at sea: 'you should come as helper, and save the well-benched ships

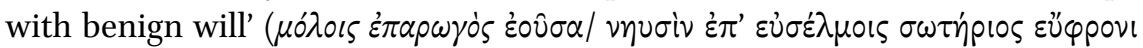
$\beta \circ \nu \lambda \hat{\eta}() .{ }^{23}$ The transmitted text of the Brothers Song encapsulates the theological hierarchy: Zeus as King (17) (and implicitly Hera as Queen [10]) stands above the daimones and, if he so chooses, can send one as a helper to ward off the perils of the sea. Like in a relay race, Sappho begs to be sent out in a procession to pray to Hera (9-10) and, implicitly, also to Zeus. Sappho can function as an intermediary for creating contact with the highest gods who can effect a reversal by sending a daimon to help. Thus the endangered person finds salvation and becomes blessed.

c) The last strophe contains a conditional statement in the following structure: the subordinate clause (protasis) with $\alpha i n \varepsilon \varepsilon(=\xi \dot{\varepsilon} \alpha)$ ) subjunctive followed by the main clause (apodosis) in the potential optative (with $x \varepsilon v$ ) indicating a consequence in the future of an unlikely but possible condition. The emphatic 'us/we' of line 13 returns in the first position of line 21; standing again in strong prolepsis, it attracts emphasis: 'we, when Larichos ...'

We could call this statement a consolation, but we must first see if Larichos really offers a solution. The protasis and the apodosis (21-24) mention two more changes (metabolai), each in two lines (c3c4). Line 24 resumes the ai $\psi \alpha$, both again in the emphatic first position, from line 16 and would entail a sudden release from the burden weighing on the mind of the performers who stand for Sappho and her chorus. The reversal (metabole), the unexpected but hoped and prayed for change, might not necessarily come through Charaxos, rather Larichos, the younger brother still in Lesbos. The subordinate and conditional clause 'if he raises his head' (21), i.e. comes into consciousness, and 'becomes a man' (22) implies a status change from youth to adulthood, and the release from

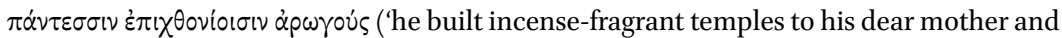
father; inside he set them up (as images) in gold and ivory very beautiful to be helpers of all people on earth', Theoc. Id.17.123-125). For a similar defense of the transmitted text, see now also Neri (2015) 63-64.

22 See $\mu \nu \dot{\sigma \tau \alpha \iota \zeta ~ \varepsilon ̇ v ~ \pi o ́ v \tau \omega l ~(i n i t i a t e s ~ a t ~ s e a) ~ i n ~ O r p h i c ~ H y m n ~ 74.10, ~ a n d ~ b e l o w ~ n n . ~} 23$ and 32.

23 The parallels of Orphic Hymn 74 with the Brothers Poem in diction and concept go even further: Leucothea is addressed as a daimon as well, a super-human force that can initiate

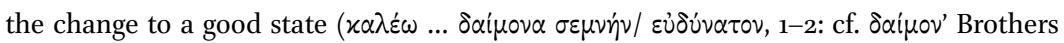
Song, line 18) and bring relief from miserable conditions and distress at sea ( $\theta \nu \eta \tau \hat{\omega} v$ oix $\tau$ pòv

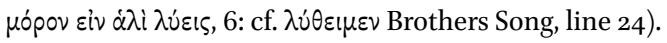


many anguishes again implies a sudden change of spirit and temper facilitating a final solution. The focus thus shifts from Charaxos abroad to Larichos in the here and now, where the 'we' stands and performs. An interpretation relying on the overlap with P. Oxy. 2289 fr. 5 , Obbink ([2015b] 4-8; and in this volume) claims that the first missing strophe already addressed the hope of Larichoswith the restoration $\lambda \alpha[\rho \subset \chi$ in line 3 on the basis of fr. 5.1-along with a mention of Sappho's mother ( $c \dot{\varepsilon}, \mu \hat{\alpha}[\tau \varepsilon \rho)$ conjectured by West ([2014] 9) using fr. 5.2. ${ }^{24}$

In terms of sound patterns, $\eta$ - and $\alpha$-syllables dominate. From the second strophe onwards we encounter a striking emphasis on $\dot{\varepsilon} x$, the movement out from Egypt, from Hades and back to Lesbos. The thrice-repeated $\dot{\varepsilon} x(15,18,23)$,

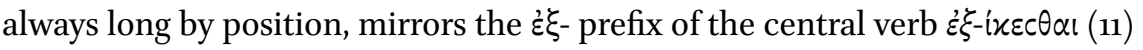
('to return and come from'), and highlights the forward movement through several metabolai. The preposition therefore underlines the notion of spatial return as nostos, the return to light and life. Hera and Zeus, the royal queen and king $(10,17)$, the leaders of the Olympian family presiding also on Mt. Olympus in Lesbos, belong, along with Dionysus, to the Lesbian triad especially present

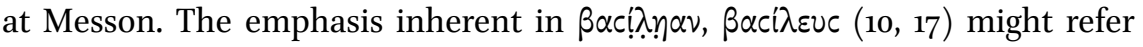
particularly to this Pan-Lesbian sanctuary. ${ }^{25}$

Both Hera and Zeus are responsible for sudden $(\alpha i \psi \alpha, 16,24)$ change, the metabole, the turn from misery to happiness, bliss, and richness. 'Royal/Queen/

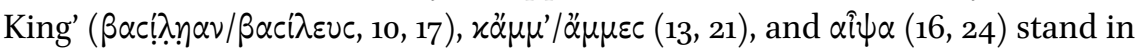
a parallel structure to a single intermittent strophe. Within the same pattern

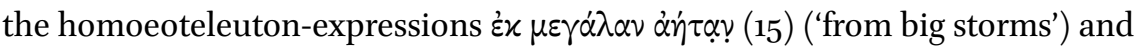

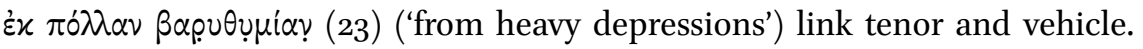
This framing device again fuses, orders, and unifies the theme, as well as paves the way for a happy ending. Everything concerns the choral performance at Messon praying for Hera and Zeus to bring about the return of missing Charaxos, sudden change, and release. The very last word $\lambda \dot{\theta} \theta \varepsilon \mu \mu \varepsilon v$ (24) might imply the third god of the triad at Messon, Dionysus, who as Lysios is often

24 West's restoration is, in fact, unlikely because it assumes that two syllables (one long and one short) precede $c \dot{\varepsilon}, \mu \hat{\alpha}[\tau \varepsilon \rho$, but there is hardly space for this in the papyrus. Therefore it is more likely that $\mu \alpha$ is a short syllable. I owe this papyrological assessment to André Lardinois.

25 Based on the locution $\tau \varepsilon i x o c \beta \alpha c ı \lambda \eta^{\prime} i o v$ ('royal wall') in Alc. fr. $130 a .15$ that a marginal scholion to line 15 of fr. P. Oxy. 2165 fr. 1, col. I designates as belonging to Hera, Ferrari $(2014,2)$ associates the Brothers Poem, where this royal title is so obviously stressed, with the Heraion at Mesa as well, particularly since P. Oxy. 2165 fr. 1, col. I is inserted between Alc. fr. 129 and fr. $130 \mathrm{~b}$ both located there. Perhaps also the 'kings' in fr. 17.4 ( $\beta \alpha c^{i} \lambda \eta \varepsilon \varsigma$ ) could have something to do with the name of this wall (I owe this remark to André Lardinois). 
responsible for the release from stress and dismal situations. The reports that Charaxos traded wine at Naucratis (Strabo 17.1.33) and Larichos served as winepourer for the Mytilenaeans in the large symposium of the prytaneion (Sappho test. 203a = Athenaeus 10.425a) also allude, somewhat indirectly, to the god of wine.

\section{The Cultural Texture of the Brothers Song}

The Brothers Song arises from the world of trade and seafaring. All its images and metaphors draw on this context; real life and metaphoric predication, tenor and vehicle, ground and figure, merge. The Brothers Poem concerns the

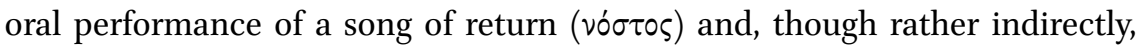
love as well. According to Douglas Frame and Greg Nagy, nostos means not only 'return, homecoming', but also, in a special sense, the 'return to light and life', nostos and vóos (mind) being related through the root *nes-, since noos is the mental activity needed to activate one's soul in order to become immortalized or revitalized by regaining consciousness. ${ }^{26}$ Interplay exists between the mental noos and nostos, since noos provides a soul ( $p$ syche) with the means to return from Hades, i.e. to accomplish a successful flight from the Underworld by becoming conscious again. The weighted meaning of this ritualistic interaction represents the underlying sub-narrative for Odysseus and Telemachus in the Odyssey, on which the mythopoetic Charaxos story draws heavily. ${ }^{27}$

Furthermore, the poem concerns love: sea, storms, ships, and shipwrecks, all nautical material, and the sea voyages themselves provide a common metaphoric reservoir for erotic tropes in Greek literature as well as for the vicissitudes of life in its entirety. ${ }^{28}$ Moreover the motifs could also resonate within the political sphere, as we know from Alcaeus' famous songs (e.g. frs. 6, 73,

26 Frame (1978) 81-115 and 134-152; Nagy (1990b) 218-219, (2013a) 275-278; see also Frame (2009) 23-58, esp. 39-45.

27 See Nagy (2013a) 275-313. On the Odyssean intertext, see also Nünlist (2014); Mueller (2016) (not seen); and Kurke in this volume. On the mythopoetic quality of the song in a very different sense, see also Peponi in this volume.

28 E.g. Hom. Od. 23.233 (regarding sex and marriage): for Penelope the returned Odysseus is like the land for the shipwrecked sailors; Thgn. 457-46o (unfaithful woman like a boat out of control), 1361-1362 (boy like a ship in collision with a rock); Pind. fr. 123.2-6 (Theoxenos

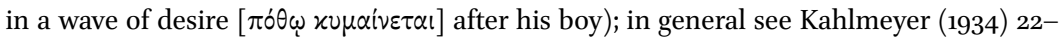
26; Henderson (1975) 161-166 (nautical metaphors for sexual congress in Old Comedy); Murgatroyd (1995). 
and 208) about ships in storms serving allegorically for the state of the hetaireia. ${ }^{29}$ Sappho might allude to the fact that her family is, to some extent, in danger, but in the strictly feminine perspective the use of this imagery applies predominantly to the erotic complex. The danger originates in love, and thus the tenor coincides with the vehicle. But at the same time, mystic and cultic notions also profoundly influence the song, meaning Sappho considers love not only as a threat but also as a feature of distinction as far as her aristocratic family is concerned. Charaxos thus assumes a mystic and almost heroic quality. Already in the recently discovered Cologne Sappho we detected a mystic dimension and a reference to Orphic mysteries. ${ }^{30}$ We discover something similar here. The adjectives $\mu \dot{\alpha} x \alpha \rho \varepsilon \varepsilon$ und $\pi \circ \lambda \dot{v} 0 \lambda \beta o r(19,20)$ serve as a special marker in this regard. Both the Homeric tradition and Herodotus use ö $\lambda \beta 10 \varsigma$ in a twofold manner. Besides its unmarked meaning 'fortunate' the attribute can refer to a special, religious, mystical meaning. Thus when Achilles (Odyssey 24.36) or Odysseus (Odyssey 24.192) are addressed as 'blessed' we can detect allusions to a hero cult after their death. Similarly in Herodotus the words have different meanings for the initiated and uninitiated. Herodotus' use of 'o $\lambda \beta 105$ in the Croesus episode (Histories 1.29-33) is a good example. Therefore also in

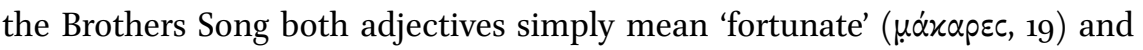
'very rich' ( $\pi \circ \lambda \dot{0} 0 \lambda \beta 01,20)$, in a secular and material sense. But for initiates their meaning blossoms to 'happy' and 'much blissed', typical markers of said initiates, who have gained a deeper knowledge, and of those who are immortalized as heroes upon death. ${ }^{31}$

\footnotetext{
29 See Rösler (1980) 115-147.

$30 \quad \operatorname{Bierl}(2008)$ and (2016).

31 See Nagy (2013a) 314-344. For both terms, makar and olbios, see de Heer (1969) esp. 28$38,5^{1-55}$ for their use in archaic poetry. He highlights the special 'emotive force' (53) of makar, a term that is normally applied to gods and the dead (since Homer [4-11, 14] and Hesiod [21-23]), but not to human beings (53). For the makarismos, the praise of the blessed condition for those witnessing the mysteries, see Hom. Hymn Dem. 480482; Soph. fr. 837 Radt; Eur. Bacch. 73-74; on Orphic gold-leaves: on trisolbios, see frs. 485.1, 486.1 Bernabé; on olbios, see frs. 485.7, 488.3, 9, 489.3, 490.3 Bernabé; on makaristos, see fr. 488.9 Bernabé. Ploutos, the personification of riches and wealth, is also involved with mysteries, esp. in the Eleusinian context: see Burkert (1987) 20; Graf (1974) 159, 180-

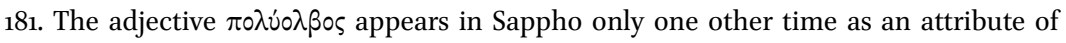

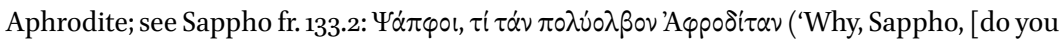
...] Aphrodite rich in blessing?'). In this context we can see some concept of "mysteries of love." On Sappho and olbios as 'emotional' expression of the 'notion of enjoyment, pleasure, sensual' regarding love that is 'given through the favour of the divine', see de Heer (1969) 32-33.
} 
Once seen in this framework, the entire poem, especially given the emphasis on salvation and the theme of the sea voyage, gains a mystic subtext.. ${ }^{32}$ In the probable ritual context actual seafaring and trade in Egypt assume a symbolic significance, perhaps alluding to the dead soul's journey, when the psyche separates from the body after death. It is well known that a dangerous sea journey often serves as a metaphor for the vicissitudes of human life and love; storms drive one to remote regions of the Other. In the Greek imagination Egypt often meant the land of death, wealth, and darkness. ${ }^{33}$ Moreover, one can become lost in strange love affairs with rich prostitutes and femmes fatales who build pyramids with the fortunes acquired from their lovers.

Rhodopis, as Herodotus describes her in $2.134^{-135}$, is such a woman, her name containing the rose (rhodon), the symbol of love. Born in Thrace she passed into the possession of Iadmon, a rich man from Samos, who also owned Aesop (2.134.3). The Samian Xanthos brought her to Egypt in sexual slavery, from which Charaxos, having fallen in love, freed her with an immense sum of money. As a professional hetaira she earned so much money that she financed the building of a pyramid and sent a rich dedication to Delphi. After her release, according to Herodotus, Charaxos returned ( $\dot{\alpha} \pi \varepsilon v o ́ \sigma \tau \eta \sigma \varepsilon v)$ to Mytilene

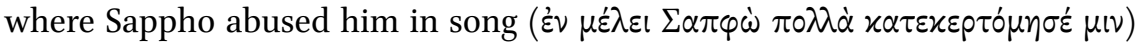
(2.135). ${ }^{34}$ Sappho herself calls her Doricha— the woman 'who gives presents', a euphemism for her trading money for love. Like Pluto, she gives plenty away only to take it back. ${ }^{35}$

Burkert (1987) 13-18 shows how the practical need for salvation, especially in regards to illness and seafaring pertains to the spread of mystery cults. In the Orphic Hymn 74 Leucothea is called to bring salvation to people distressed at sea and for their ships as

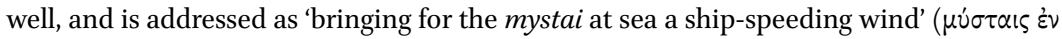

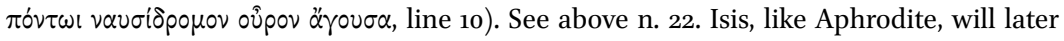
function as a patroness of seafaring. Safe return from distress at sea can also serve as a metaphor for salvation from the storm of life.

33 Menelaus got lost in Egypt without hope of return (Od. 3.319-320). For Egypt as the land of death in Eur. Hel., in which the reception of Menelaus' adventures (Od.4.351-586) plays a big role, see Jesi (1965); Wolff (1973) esp. 62-68; and Rehm (1994) 121-127.

34 The personal pronoun $\mu \mathrm{v}$ theoretically could mean also 'her', i.e. Rhodopis, called Doricha by Sappho. So Lidov (2002) and Ferrari (2014) 10. See also Obbink (2014b) 41. Lardinois in this volume (p. 170) argues against this theoretical option. Sappho perhaps attacks Doricha in fr. 15, but she is spoken of in the third person. Thus it is more likely that the person addressed (and truly criticized) is Charaxos.

35 See also Strabo 17.1.33; Athen. 13.596bc. For 'Doricha' as a nickname for a courtesan, see Schlesier (2013) 205, 207. For eventual mystic connotations, see the formula 'Hermes, the 
Sappho's song of abuse is lost, and before the discovery of the Brothers Poem we had no song that explicitly mentioned Charaxos—only in fragments 5 and 15 does he seem to play a role though he is not mentioned by name. We only had testimonies about Charaxos and two other brothers, Larichos and Erigyios. ${ }^{36}$ But with the Brothers Poem we now have a detailed song mentioning both Charaxos and Larichos. As said, nostos means 'return to light and life' from the lands of death and darkness, implying a great effort in escaping and traversing the liminal sea to reach home and salvation. The mystic meaning of happiness might be programmatically inscribed in the name Charaxos, containing $\chi \alpha \rho \alpha$ ('joy, pleasure'). ${ }^{37}$ Somehow he becomes the eroticized emblem of an idealized man, a focus of interest for Sappho and her circle, an imaginary and heroic model of an immortalized bridegroom. ${ }^{38}$ We hardly have an explicit indication of such a positive image of Charaxos in the fragments or testimonia, but Sap-

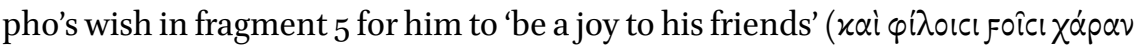
$\gamma^{\varepsilon} v \varepsilon c \theta \alpha$ l, 6) could possibly mark a turning point in this regard. Since Sappho knows about Charaxos' positive qualities, after all her criticism and rebuke she wishes to make the audience, as well as her circle, aware of her brother's higher, almost mystic and heroic attraction.

Numerous songs circumscribe the eternal gap of desire. Likewise in this poem the goal, the object of sisterly love, is almost unreachable, absent, or at least endlessly deferred. Even though Herodotus tells us that Charaxos did ultimately return, in Sappho's restricted, emotional perspective he seems so beautiful that he became lost in the realm of the Other to a most desirable woman. She knows that prayer alone could help make him sail back to Lesbos. Only Zeus and the gods can thus aid in calling him back and forcing him to

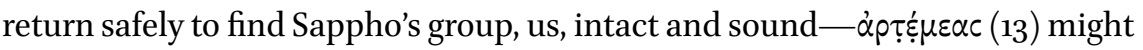

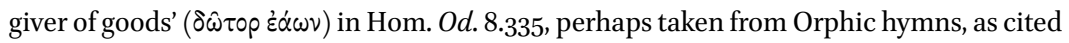
in P. Derveni col. 26.2 (with Bierl [2011a] esp. 395).

36 Sappho test. 213A (b, d, h; perhaps c and e) = fr. P. Oxy. 2506, a commentary on lyric poets, fr. 42 (a), fr. 44 col. ii, fr. 48 col. iii; perhaps fr. 43 col. ii, fr. 45 ; Sappho test. $25^{2}=$ P. Oxy. 1800 fr. 1.1-35; test. 253 = Suda $\Sigma 107$, and the various sources given under Sappho test. 254 (on the Rhodopis narrative). On Larichos as a cup-bearer, see Sappho test. 203a and b.

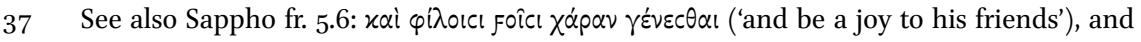
on the 'possible word-play', see the commentary by Burris, Fish, and Obbink (2014) 24. On $\chi \propto p \alpha$ (joy, pleasure) as feature of the initiates, see the Orphic gold-leaves, fr. 487.3, 5 Bernabé ( $\chi \alpha \hat{p} p \varepsilon)$.

38 Charaxos would thus become a complementary figure to Achilles who, according to Nagy (2013a) 109-145, esp. 115-116, 136-140, functions as an 'ideal' and 'eternal bridegroom'; see also Nagy (2007a) and (2007b). 
even allude vaguely to Artemis as Plato's uncertain etymology suggests (Craty-

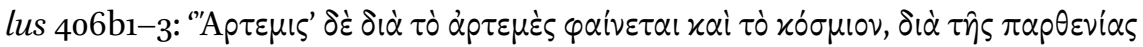
$\dot{\varepsilon} \pi \theta \nu \mu i \alpha \nu$ - "Artemis" seems to come from intact and well-behaved, because of the girl's love'). ${ }^{39}$ This implies that the girls transitioning to adulthood remain chaste like the goddess. Through their intervention the "ideal bridegroom" Charaxos, finds his way back from death and love to life and pre-sexual status. In other songs Sappho as a generic persona may have symbolically reproached him (see Herodotus 1.135.6), when he finally returned, for his notorious excessiveness in this mythic, or quasi-mythic, tale imitating life; he fails as a potential husband, abandoning himself to prostitutes. Yet by portraying Charaxos in this manner the performers succeed in shaping an eroticized and heroic model. In an extremely feminized focus, the protracted "ideal bridegroom's" absence creates desire, the sensation of being wounded, in the girls' imagination, who themselves become desirable as a consequence. Praying intensely, they seem to believe that whenever Charaxos hopefully returns, he will surely regret his mistakes and become an honorable citizen again. ${ }^{40}$ And he would find them 'safe and sound' or even 'unwounded' since his prayed-for presence would bring an end to the wounds in their hearts.

In archaic poetry, ritual often frames and interacts with myth. Myth usually narrates deeds that fail, whereas in ritual the same are felicitously achieved. ${ }^{41}$ It is well known that the essential context for the Sapphic circle is the female rite of passage from adolescence to adulthood. In idealized scenarios the girls learn the all-encompassing values of beauty (kallos). In choreia they incorporate beauty in multimodal practices acted out with their bodies. ${ }^{42}$ While they

The 'us' in lines 13 and 21 would thus not stand necessarily for the 'I' and 'you', as all scholars seem to take it. The 'we' might also somehow include the 'you' and thus the entire clan. But in her female perspective the focus is much more on her group and the implications of Charaxos' return for the circle. Sappho and the girls have felt the "wounds" of the absence of the beloved-in the Homeric meaning for $\dot{\alpha} \rho \varepsilon \mu \eta \dot{s}$, , 'unwounded' from the battlefield (e.g. Il. 5.515) —and long for his arrival when they would be 'unwounded'. Sappho thus plays with the vocabulary of war for her non-marital situation also in this poem. For this use, see Rissman (1983).

40 See Sappho fr. 5 with the additions of P. GC fr. 3 col. ii.10-29 and the commentary by Burris, Fish, and Obbink (2014) 11 and 23-27; see also West (2014) 5-7 and Ferrari (2014) 4-9.

On the interplay of myth and ritual in general, see Bierl (2007a) esp. 12-16; in the ancient novel, in particular on the model of initiation, see Bierl (2007b) esp. 243, 249-251, 265276, 298-299. As far as Dionysus and drama are concerned, see Bierl (2013a) esp. 366 (on comedy): 'Scenarios of inversion are located basically in myth, while phenomena of group cohesion such as festivity, enjoyment, and happiness are based in cult.' 
succeed and are thus prepared for their marriage, the complementary myth of the young man's rite of passage fails, or is at least endangered by the terrible scenarios of death and perverted sexuality.

Since Charaxos' return lies in the hands of the gods, Sappho (with the 'you' somehow included) and her circle, the 'we', suggest in the final strophe that they make do with the younger brother. Larichos also undergoes a rite of passage, but has not yet reached the threshold of adulthood. In contrast to his older brother, he is still at home. Athenaeus (10.425a) (= Sappho test. 203a) tells us that he poured the wine for the Mytilenaeans in the Prytaneion, and the scholiast T to Il. 20.234 (= Sappho test. 203c) explains 'it was the custom, as Sappho says, for handsome aristocratic young men to pour wine (oinochoein)'. Ganymede, the most beautiful young man, served as a mythic model, abducted to serve Zeus as cupbearer in Olympus. ${ }^{43}$ If Larichos 'raises his head' (21) - also meaning, if he returns to consciousness and full life, leaving his ephebic and initiatory transition status as a ritual servant and becoming finally 'a man' (22) — they, the 'we', 'would be freed suddenly from their many anguishes' (23-24). Also his name, possibly understood as a 'speaking name', is programmatic: $\lambda \alpha$ pós with a long $\alpha$ means 'pleasant',-_joyous', Charaxos, thus finding its substitute in 'pleasant', Larichos, once the crisis of puberty has passed.

Larichos' activity as a cupbearer in the aristocratic symposium more than adumbrates his deep involvement in love as well. Around 6о0 BC the Greek aristocracy began to install beautiful boys as wine-bearers more for leisure, prestige, and erotic amusement than for education as in former times. It became fashionable in Sappho's time to have these boys as objects of an idealized and passionate love. ${ }^{44}$ Ganymede modeled this new male homoerotic practice of the élite. ${ }^{45}$ Specific families and clans, like Sappho's own, the Kleanaktidai, notorious for their aesthetic affectations of luxury and wealth, also aimed to distinguish themselves with a new erotic way of life: the Lydian fashion. ${ }^{46}$ The Kleanaktidai coveted abrosyna (elegance, luxury, sensuality), ${ }^{47}$ which Sappho

43 On Ganymede abducted by the gods: Hom. Il. 20.232-235; from Zeus alone: Hymn. Hom. Ven. 202-206; Ibyc. 289; Thgn. 2.1345-1348.

44 See Breitenberger (2007) 178-182.

45 See Breitenberger (2007) 182-183.

46 See Ferrari (2010) 5, 11-16, 17-18.

47 Ferrari (2010) 17-18; Kurke (1992); regarding the last four lines (P. Oxy. 1787 fr. 1.23-25 and fr. 2.1, the last two known through Clearchus fr. 41 Wehrli cited by Athenaeus 15.687b) of Sappho fr. 58.23-26, see Kurke (1992) 93-99, who interprets the word $\alpha \beta p o \sigma \dot{v} v \alpha$ not merely in material but also in political terms, in the sense of an aristocratic, oriental luxury; 
praised in various poems, ${ }^{48}$ and began, in this vein, to romanticize the homoerotic male youth. Thus Larichos' behavior leads us to believe he also has fallen prey to Eros who somehow personifies these idealized boys in their duty as wine-pourers in the new symposium. ${ }^{49}$ While the bonds of heterosexual love bind Charaxos, Larichos is engaged in homosexual affairs. His bowed head signifies his lack of personal freedom. He has become a slave of desire, the object of lust for adult males. ${ }^{50}$ So immersed in the erotic fantasies of the symposium he can only become an adult if he 'raises his head' (21) and 'becomes a man' (22), and ceases to be a sexual object. Therefore Larichos, likewise a victim of desire and love, is far from a real alternative for the lost Charaxos. However, we must ask ourselves if this implies a reproach to Larichos as well. ${ }^{51} \mathrm{Or}$ is it simply the course of life and in the nature of her clan that both her brothers, like Sappho herself, dedicate themselves completely to love? Passion brings anguish, suffering, and troubles, but as generic figures both her brothers simply represent the quintessentially Sapphic way of life, which she presents to her group and praises in many songs.

Moreover Aphrodite, the goddess of love and the patroness of Sappho's circle, implicitly present in the poem though not mentioned, functions in her roles as Euploia, Pontia, or Limenia as the goddess of seafaring (Paus. 2.34.11),

on these lines and $\alpha \beta p o \sigma u v v \alpha$ as 'luxuriance' ... 'connected with the concept of Lydia as touchstone of sensuality', implying also a certain amount of danger and pathos, see Nagy (1990a) 285-286; see also Bierl (2008) ch. 5 'Das Ende des 'Altersgedichts' (в) und OrphischSolares' and Bierl (2016) 326-330 'The End of the "Old Age Poem" (в)'.

48 See Sappho fr. 58.23-26; on $\alpha \beta$ pos, see Sappho frs. 2.14 (Aphrodite), 128 (Charites), 44.7 (Andromache as bride), 140.1 (Adonis), 100 (cloth). See also Ferrari (2010) 66-71.

49 See Breitenberger (2007) 171-194.

50 Obbink (2015b) 8, on different grounds, also finds Larichos as wine-pourer to be in a state of love at the symposium. On the basis of Anacreon fr. 346 fr. 4.1-2, where boxing Eros knocked down the speaking 'I', who raises his head again, and following a suggestion by Schlesier, Obbink (2015b) 8 conjectures a sentence filling the large lacuna in the missing first strophe preceding P. Oxy. 2289 fr. 5.1-2 supplemented by West (2014) 9

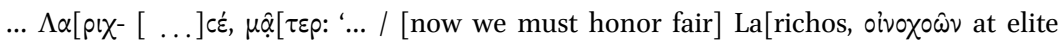
banquets:]/ [with him, Eros wears boxing gloves (vel. sim)—and] you [should celebrate him,]/ [too,] Mo[ther].' In test. 203a Sappho 'praises' Larichos for his honor of serving the wine in the town hall of Mytilene. Although, Sappho is proud of this aristocratic award for excellence, she nevertheless understands that this service has new, erotic implications. Moreover due to her focus on love, she highlights here how Eros subdues the young man, stripping him of all his aristocratic autonomy, rather than expressing the family pride.

$5^{1} \quad$ As Martin claims in this volume. 
as does Hera, ${ }^{52}$ who as wife of Zeus and goddess of marriage watches over the path to adulthood and the loss of direction in general. ${ }^{53}$ Furthermore, as seen above, sea travel can serve as a metaphor for love adventures and mystic adventures. Thus love and mystery overlap with actual sea trading and sea voyages. Sappho employs this bio-mythic discourse to speak indirectly about love, if in a tonality different to those songs where she directly addresses eros or himeros.

\section{The Link between the Brothers Poem and the Kypris Poem}

As Obbink ([2014b] 35) remarks, the beginning of Sappho's first book featured an alternation between two sorts of songs: ${ }^{4}$

(i) family and biography and/or cult, for adults, and

(ii) unrequited passion, for adolescents, while offering a window into adult experience, since the speaker repeatedly represents herself as having experienced these things in the past.

The Brothers Song, according to Obbink and, presumably, most critics, belongs to the former category, the Kypris Song to the latter. But, as we have seen, the first group is not so different from the second, both deal with love. Charaxos was an ongoing topic as various testimonies, probably based on Sappho's poems, attest. ${ }^{55}$ And we are lucky that glimpses of Charaxos and his story have survived in our existing fragments: The story of Charaxos (here unnamed) and Doricha seems to play a vital role also in fragment 3 , where we have words of reproach. Fragment 5, a propemptikon for Charaxos, again not named, which according to the new discoveries of the Green Collection inv. 105 must be placed after

52 On this aspect of Hera, see her title Epilimenia in Thasos, IG XII Suppl. 409 and the small votive boats for her at the Heraion in Samos; see also de Polignac (1997) esp. 116, and Boedeker in this volume.

53 With the new readings supplied by P. CG inv. 105 fr. 2 col. ii for Sappho fr. 17 the Kallisteia seem to have been celebrated not only by women but also by young girls ( $\left.{ }^{\prime}\right] \times \lambda \circ \mathrm{c} /$ $\pi \alpha p \theta \varepsilon \hat{\varepsilon}[\nu \omega \nu \ldots \gamma] v v \alpha i x \omega \nu, 13-14=$ P. CG inv. 105 fr. 2 col. ii.21-22) at Messon as a choral rite of passage. On Hera responsible for the transition to marriage and adulthood, see Calame (2001/1997) 113-123. On Sappho fr. 17 see also Nagy and Caciagli in this volume.

54 With the new papyrus discoveries we again glimpse this alternation. On the idea of an Alexandrian collection on a thematic basis, see now also Neri (2015) 71-73.

55 See above n. 36 . 
fragment 18, exhibits many similarities to the close Brothers Song. ${ }^{56}$ Fragment 7 addresses Doricha and her arrogance, obviously dangerous for young men. Fragment 9 (with the new additions of P. CG inv. fr. 105 fr. 1, placed after fragment 5 and probably immediately before the new Brothers Poem) might be a prayer to Hera on Charaxos' behalf, as in the Brothers Poem. ${ }^{57}$ Fragment 15 names a goddess makaira, perhaps Aphrodite Euploia (2), and the speaking I wishes that Charaxos may atone for past mistakes and reach the harbor with fortune-a possible allusion to Aphrodite Limenia (7), but perhaps the goddess is again Hera, also responsible for seafaring. It might be a negative propemptikon directed at Egypt: Doricha 'may find' the addressed Kypris 'very harsh' and she 'should not boast that Charaxos came a second time to a desired love' (912). ${ }^{58}$ Fragment 17 could again be a propemptikon for Charaxos, performed in a choral group at Messon for Hera. ${ }^{59}$ Whatever the scenario of this song may be, the performers, as in the Brothers Poem (9), reenact the procession and, as in the mythic precedent of the Atreids, who did not find their way home (fr. 17.2-10), they perform as a 'holy crowd of girls and women' a series of rituals, probably a sacrifice with the ololyge-cry, and pray for someone to come $(11-20) .{ }^{60}$ Last but not least fragment 20 may have a similar trading and seafaring context.

56 Especially the appeal to come hither: $\tau v^{\prime} \delta^{\prime}$ ' ix $\varepsilon c \theta \alpha[\iota$ ( $2 \sim$ Brothers Song, line 11: $\dot{\varepsilon} \xi i x \varepsilon c \theta \alpha$ เ

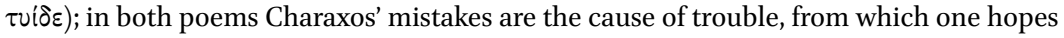

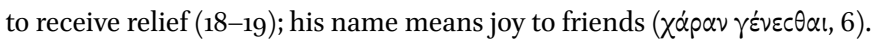

57 Pace West (2014) 7-8, who on the basis of P. CG inv. fr. 105 fr. 1.1, supplemented $\mu$ ] $\hat{\tau} \tau \varepsilon \rho$ for Sappho fr. 9.3 by Burris, Fish, and Obbink (2014) 15, thus regards it an appeal to mother Kleis (as in the Brothers Poem), who had announced that she cannot finance a festival (źóp $\tau \alpha \nu)$ any more. I prefer to interpret "Mother" as an epithet for Hera despite Burkert's ([1985] 133) important remark: 'One feature strangely missing from the portrait of Hera is motherhood ... Never is Hera invoked as mother, ...' Perhaps this passage is the exception; see already Alc. fr. $129.7 \pi \alpha \dot{\nu} \tau \omega \nu \gamma \varepsilon v \varepsilon \dot{\theta} \theta \lambda \alpha \nu$ ('Mother [i.e. origin/generation'] of all) in a poem also performed at Messon.

$5^{8}$ The exact reading of these lines of fr. 15 is far from certain; see the contributions of Lidov and Lardinois to this volume.

59 Caciagli (2011) 155-157 argues for this; see also Caciagli in this volume and Neri (2014) 22. Neri (2014) 23 n. 76 and (2015) 56, 67, 69 even suggests that the Brothers Song could be the monodic prelude to a choral song and that the prayer-hymn to Hera in lines 10-13 might actually be the hymn transmitted as fr. 17; see also Caciagli (2011) $153^{-156}$ and Caciagli in this volume.

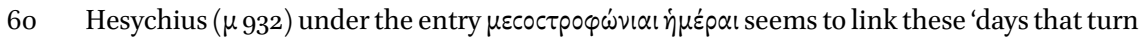
at the middle' and the related federal festival, celebrated with a common sacrifice, with Messon. The name may recall a seasonally repeated year-festival when the days become 
We must ask ourselves what the striking alternation between sibling poems and songs about unrequited love within the circle implies. Furthermore we must tackle the question of whether the first group really constitutes a biographic cycle about Sappho's brother and his vicissitudes-a methodological issue. If we follow the pragmatic and older biographic approach in a strict fashion, we are faced with the question of where Sappho could have uttered thoughts about her brother. Possible occasions are the symposium or other gatherings of the hetaireia, where Sappho's poems, with and without her presence, might have been performed. Or she may have performed them in her circle to reflect upon her family. Some songs were probably choral, sung at Messon, appropriating the perspective of its choral leader Sappho. A chorus could thus have prayed to the famous triad, especially Hera, to bring Charaxos home in the Brothers Song as well.

But why should she constantly bother her audience with the personal affairs of her brother? Most likely he existed, but even that cannot be proven. His excessive lifestyle, independent of his existence, could have served as a negative foil for males in the clan and for the girls in the circle-for which reason the negative paradeigma of the prostitute Doricha also comes to the fore. But, as seen above, Charaxos' personality can also be used as a positive, quasi-heroic model. Heroes, notoriously ambivalent and transgressive in life, become purely positive after death. Moreover we have to consider the possibility that Sappho mentioned her brothers in a more or less fictive, generic, idealized and personalized sense as almost everyone in the audience and the circle has a family consisting of brothers, daughters, and husbands and wives. The female gender of the speaking 'I' almost necessitates this family constellation. The personae involved are somehow 'good to think with' ${ }^{61}$ Sappho and/or her chorus communalize a "private" experience easily comprehensible for everybody to speak about something else.

Obviously the common denominator of the alternating sequence, present also in our new papyrus, is love. Of course, this does not necessarily represent the performance context, and the Hellenistic papyrus places both songs, the Brothers and the Kypris Song, together because their initial letters were а п. In the Kypris Song and the songs of the second category (ii) the erotic experience turns homoerotic but is also general to an anthropology of human love that

longer or shorter after equinox. On a metonymic level this 'turn' might be the metabole of the Brothers Poem, which is ritually highlighted by the sacrifice and the song, prayer, and dance of Sappho's chorus. The ololyge-cry is notoriously associated with a thysia; see also Nagy in this volume (p. 475).

61 Lévi-Strauss (1962) 89. 
extends to heterosexual relations. These songs speak of love in an idealized and elevated manner, revolving around the quintessential 'discourse of absence, ${ }^{62}$ that gap of desire that never really closes. The first category (i), especially the songs about Charaxos in the first twenty fragments of Book One, deals with a decadent form - at least in the ethically strict and aristocratic conduct of the Sapphic circle - of heterosexual love, specifically the male erotic encounter with pornai, prostitutes or courtesans. Although this sexual behavior might find some support as an aspect of politics of habrosyne supported by Sappho and her clan, it causes the loss of economic stability and honor (time) in his familymeaning severe consequences for its female members as well. The brother, to some extent, does not fulfill the expectations of an aristocratic marriage. But he, still a young man, should conclude his rite de passage solemnly with an adequate wedding at home in Lesbos.

Following Charaxos on his real, fictive, or stylized trips over the sea, we see a trader, who makes a fortune abroad only to risk losing it-according to Herodotus, he really lost it - to a freed female slave and whose return is precarious. The Sapphic group must face his death or extinction, since he, losing himself in the Other, may never take the decisive step towards successful reintegration into his polis. However, despite all his mistakes (see frs. 5.5, 15.5), Sappho is also deeply attached to her brother and yearns to have him back, longing to see his honor reestablished and his profit secured for the welfare of the entire clan. After all, we are confronted with a narrative about the intimate love of a sister for her brother gone wild. Her concern extends beyond his conduct to its implications for the entire clan and the nuclear family. To some extent, these poems take on a political aspect seen through the lens of the female gender-role. As a woman Sappho stays at home and leads an aristocratic life, like Penelope, while Charaxos goes abroad, like Odysseus and other epic heroes, and falls prey to sexual and dangerous affairs. Despite the depravations there is still love, and Kypris is responsible for Charaxos' attraction to Doricha, the femmefatale. Therefore Sappho not only criticizes and reproaches Charaxos, shaping an erotic reflection as the negative foil, but also, at least to some extent, admires the paroxysms of love. Afflicted by love, people become mad and risk losing everything.

At the same time, Charaxos becomes a positive and idealized model of the beautiful future bridegroom for the girls in the circle. ${ }^{63} \mathrm{He}$ morphs into an unreachable and idealized hero after being immortalized by his love affairs,

62 Barthes (1979) 13-17.

63 See above n. $3^{8}$. 
something realized only after his death. As long as hope for his return remains, he can simultaneously be slightly criticized for his non-aristocratic conduct. But the 'I' and 'you' seem rather unaware that Charaxos has spent the family fortune on Doricha and still hold out hope that he may come back with a full ship. In a potential case of dramatic irony, the audience may know what happens. Be that as it may, Charaxos' return might entail the possibility of marriage following his successful reintegration into society. Therefore the Charaxos songs form a chain of stylized and idealized cases and situations for how to position oneself as a woman. Only pious behavior and group prayer can bring him back. The relationship between Sappho and her brothers becomes a communal experience of love and desire on a more official occasion in the polis or at Messon, whereas category (ii) might have been restricted to the circle. However, category (i) can also be successfully applied as a tool for paideia in the circle.

Indeed, the more or less alternating manner ensures a focus on the phenomenon of eros. Even Larichos, likewise stylized as a generic figure, does not offer an alternative, since as wine-pourer he is likewise lost in the realms of love. Sappho probably wants to present a possible solution. Only when Larichos lifts his head' (21) — the lowered head symbolizes slavery to Eros—and stops fulfilling his role as an object of erotic desire, becoming a real man (22), might the group be relieved of its heavy weight and suffering (23-24). But as we deduce from the Kypris Song, Sappho laments her own as well as her brothers' suffering and state of being entangled in passion, praying for respite. Obviously she projects her erotic lifestyle onto her entire family as if to say: 'I too, as both my brothers, the older and the younger, am made for love. I might pray for delivery but all is in the hands of the gods. They can bring Charaxos back, initiate change and the transformation to manhood. Those whom the gods help are blessed. But isn't the state of love also some sort of blessedness, lovers closely tied to Aphrodite and Eros who rend them, hurt them, and bring them close to a state of death?'

\section{Scenario and Content of the Brothers Song}

We have a complex communicative situation:1) a 'you', who repeatedly chatters about Charaxos returning with a rich ship; 2) a singing 'I', Sappho as author, poet or choragos, who offers an alternative standpoint; and 3) a 'we': the 'I' subsumed, either (a) Sappho's circle; (b) the female chorus performing prayer; (c) Sappho's family and wider clan; or (d) the plural of the 'I' and 'you' persons interacting here. 
Obbink ([2014b] 41-42) defines the following scenarios concerning the 'you':

(i) She responds to another concerned person (her mother?), saying in effect, don't just keep saying what you want (i.e. for Charaxos to come), but send me to pray.

(ii) She responds to someone saying to her: "[he's not coming back] but you are always chattering that Charaxos should come." She says: the gods know these things, as you should know. We should pray to them.

(iii) She counters reports of a hetaira who keeps chattering that Charaxos will or has come in the past (aorist with past time) or should come now - to her "with a full ship", saying to her: don't tell me what the gods know and what is wrong for you to think; it's right for me to still try to save the situation ...

Obbink ([2014b] 42) finds the first scenario the likeliest'. 'Sappho is engaged in gentle banter with her mother (or another family member) over the correct attitude to be taken toward her brother's extended absence, in which she contrasts simple repeated wishing with the pious ritual act of prayer in accordance with human subordination to the gods' wishes'. I think he is basically right.

But let us go into more detail:

(1) the chattering 'you' can be her mother or

(2) another family member

West ([2014] 8-9) argues for (1) and on the basis of the remnants [ ...]cź, $\mu \alpha[$ of the overlapping P. Oxy. 2289 fr. 5 line 2 that provides the adonean of the first missing strophe, conjectures $c \varepsilon, \mu \alpha \hat{\alpha} \tau \varepsilon \rho$, the missing mother. Obbink ([2015b] 7) agrees and, on the basis of Ovid's Heroides 15.61-62, even tries to insert in the first line Sappho's father, who died very early, as well as Larichos, the potential hope for the future, conjecturing for the two letters $\lambda \alpha$ in P. Oxy. 2289 fr. 5 line 1 $\Lambda \alpha\left[p i X^{-64}\right.$

Despite Obbink's and West's tempting suggestions I still argue for (2), believing strongly that such a friendly and intimate discourse with her mother does not fit the situation. Moreover Sappho, at this stage of her career, seems too powerful to portray herself disputing essential matters regarding the economy

64 On a detailed evaluation of all possibilities, see now Neri (2015) 58-6o, who also pleads for the mother $(60)$. 
and politics of the oikos and clan with her old mother. The only instance, in which we hear about her mother Kleis, concerns a gentle and intimate exchange of the past, about female appearance and fashion, when Sappho herself was a young girl. In Kleis' own youth it was a great adornment (kosmos) to wear a hairband, superseded later by a new fashion from Lydia, the mitra (Sappho fr. 98a). But now Sappho cannot obtain such luxurious headgear for her own daughter, called Kleis after her grandmother, since her clan, the Kleanaktidai are in exile (fr. $98 \mathrm{~b}$ ). Furthermore, I believe that instead of an intimate conversation between two females we have a harsh dispute requiring a strongly gendered aspect. ${ }^{65}$ Thus even as an adult woman Sappho argues in a perfectly suitable manner for the aristocratic, female decorum, but for Kleis, the old lady of the house, it would have hardly been regarded as proper to advocate the purely economical standpoint the 'you' here represents. ${ }^{66}$

As we have seen above, the Kleanaktidai are fond of Lydian wealth and abrosyna, but females display their clan's programmatic value differently than males. Women, on the one hand, exhibit luxurious dress, and Sappho uses the discourse about external fashion and kosmos to instill in the girls of her circle the values of inner beauty (kallos). Men, on the other hand, openly advocate for a program of luxury with political and entrepreneurial economic activity. The stage is set then for a dispute between a leading male and female figure regarding new aristocratic values which breaks along gender lines, especially when it turns to the roles of love and trade in a society of risk. Overseas trading, met with aristocratic contempt until recently, involves a great amount of danger: the loss of the ship, the cargo, and even life looms. Charaxos, the male exponent of the oikos and clan, pursues the policy of the Kleanaktidai of accumulating wealth, striving for abrosyna and eros. In doing so he falls prey to a hetaira on whom he wastes the family capital. Obviously some members of the clan believe Charaxos fails to model proper behavior but still insist everything will turn out fine. Sappho, in her sisterly affect, emphasizes that the situation is not so simple and offers a solution appropriate to her gender, a procession to Hera's shrine and a prayer in choral voice at Messon asking the gods to return

65 See Stehle and Lardinois in this volume; see also Kurke in this volume, who, on the basis of a different theoretical gender perspective from Teresa de Lauretis' feminist film theory, nevertheless pleads for the mother as internal addressee. Through the intimate dialogue with her, the other space, the view within the oikos, would thus be integrated. Bettenworth (2014) thinks that the harshness of the tone speaks against an exchange with the mother. Therefore she pleads for the nurse noting interesting parallels, but it is hardly plausible that a nurse could have the authority to send Sappho to pray at Messon.

See also Nünlist (2014) 13 . 
him safely. Thus the performance of the song mimetically enacts prayer and is in fact prayer. Sappho knows the goal will be hard to reach, but through performance she compensates for the loss, lionizing, indeed almost heroizing, the missing Charaxos, and making clear that her aristocratic family is totally dedicated to love. She does all this from her sisterly position, the quintessential instance of love. Sappho, by highlighting her status as sister, also draws the choral group into a 'sisterly' role giving special importance to love, even though Charaxos' perverted love might ruin the house. The singing 'I' represents female modesty and religiosity so that all erotic adventures end happily.

Because of the evident gender aspect, I argue for an important male family member, presumably an uncle, probably maternal. On similar premises André Lardinois considers the possibility that the addressee is the third brother Erigyios, who is mentioned in the testimonia, but not in connection with this specific exchange. ${ }^{67}$ In his contribution to this volume Lardinois draws attention to the fact that, with Sappho's father Skamandronymos (or Scamander) dead, as we know from Ovid's Heroides 15.61-62, and in the absence of the eldest brother Charaxos, Erigyios would have been Sappho's kyrios according to Greek family law. Thus he would play the same role I attribute to the maternal uncle. But the uncle, being beyond the age of erotic entanglements, pleads for an extremely economic and rational way of life, while I would argue Erigyios is still so young that even as a kyrios he would automatically adjust to the erotic agenda of his family and cannot play this role in the poem. ${ }^{68}$ The expression 'to chatter' (5), strongly derogatory and pejorative, indicates that Sappho is not engaging in a friendly mother-daughter exchange, but rather in a stronger dispute about fundamental values. The 'you' represents a strictly male view, secular and more superficial, economically based. He wishes Charaxos back, but does not reflect deeply because he has only profit in mind and ignores the theological foundation of success. Therefore he simply utters repeated consolations: 'Charaxos will return'-'and with a full ship' (5-6), i.e. the income will not be lost. Sappho should be likewise optimistic. He completely trusts in Charaxos' sailing experience and represents the new type of the 'Könnens-Bewußtsein', 'the consciousness of ability' to achieve everything as a human being. ${ }^{69}$

67 See Lardinois (2014) 191; see also Caciagli in this volume.

68 In the mythopoetic pattern I would expect Erigyios too to be in love and Sappho to sing about it. But in the scenario of the Brothers Song, the middle brother is left aside since he is of no help either.

69 See Meier (1990) 186-222; 'the consciousness of ability' seems to start not only in the $5^{\text {th }}$ century в $\mathrm{c}$ but also traces its origins back to the crisis of aristocracy and the new economic orientation at the turn from the 7 th to the 6th century BC. 
Money drives trade, we must take into account that the Lydians had invented electrum coinage only a generation previously. As is reflected in Sapphic poems, the Kleanaktidai in nearby Mytilene grew very fond of the new Lydian lifestyle. With the economy booming, even the young aristocrat Charaxos leaves his environment to make a fortune trading Lesbian wine for other luxury products in Egypt. The uncle will have supported Charaxos in this endeavor. But we know firsthand, and accounts from Hesiod's Works and Days (646-693) and Solon (fr. 13.17-24), as well as Sophocles' first and second stasima of Antigone (332-375, esp. 333-337 and 583-625, esp. 586-592 [storm at sea]) provide evidence that seafaring remained extremely dangerous and still could be viewed as hybris.

Sappho, a strong personality and important family member, takes a traditional and typically female position against this new way of thinking. The song represents a fictionalized form of familial dispute between the generations, a sort of power struggle communalized in words performed in a ritual act at Messon. A possible scenario of this fictive, allegedly private conversation could be the following: the uncle probably used Charaxos' absence to install and broaden his influence in the hetaireia. The consoling attitude might be a paternalistic gesture to keep Sappho's family quiet. In reality it pleases the uncle that Charaxos will not be coming back as the latter's absence allows the uncle to keep his powerful position. However Sappho, as new speaker for the aristocratic family — and she wants to stake a claim for its further influence-, reacts in an unexpectedly harsh manner. Yet, like Penelope in the Odyssey, she knows her limits. Therefore, according to male expectations, she respects her gender-role by not claiming power herself but for her younger brother Larichos, although he is still immature and entangled in erotic affairs. Her strategy is not to digress from the path of the traditional, pious, and chaste behavior. After all she only opposes her uncle with words, the rather harsh and derogatory expression 'you chatter' at the beginning - but she might also allude to his unreflective attitude as older man: if he had reflected deeper, he might have reached a different conclusion. Sappho's dissent then becomes more gentle: she does not say 'I know for sure that it is like that', but chooses the careful and modest formulation 'I think' (olopal, 6). Furthermore, she argues on the basis of the traditional view of religion: 'Zeus knows' - a concession to the male perspective, though still under the predominance of Hera addressed later in the prayer-'and all the gods' (6-7). $\cdot^{70}$ All knowledge lies in the hands of the gods; they may use noos to activate Charaxos for his return-or not. 
Archaic Greek women have a subordinate role in society but can exert influence in their cultic and religious roles-exactly as Sappho implies here. Therefore she dares to formulate a religiously motivated, ethic command: 'it is not necessary' — or better - 'you are forbidden ( o $\chi p \hat{p})$ to think these things ( $\tau \alpha \hat{\tau} \tau \alpha$ vónc $\theta \alpha \mathrm{l})$ ' (7-8): meaning, 'uncle, beware, you've interfered in the sphere of the gods; you do not have the power and legitimacy to think or to use noos to activate Charaxos in these terms': rather the gods must bring noos for nostos, and change his mind to make him return. ${ }^{71}$

with the cultic reality of Mytilene, Lesbos, and Messon, which served the whole island as common sanctuary; see the Hellenistic decree of Mytilene recorded in an inscription SEG 36.750, са. 33 вс, where we find the confirmed predominance of the Olympian couple. It still reflects to some extent the archaic circumstances and the gendered dichotomy transcended by Sappho. Similarly we see that Hera is the main player of the Twelve Olympian gods, even her husband Zeus subordinated to her, invoked with the epithet Heraios ( $\Delta \iota \imath \tau \hat{\imath} \iota$ ' $\mathrm{H}-/ \rho \alpha i \omega \iota, 6-7)$. The last goddess addressed in the series, 'the one who

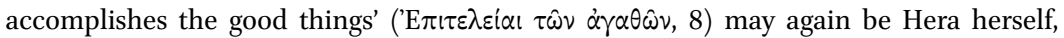
bringing everything to the telos, the guarantor of justice and harmony, the objectives of the prayer addressed as the personifications Dike and Homonoia (7). See Pirenne-Delforge and Pironti (2014). In terms of maturation the telos, in the domain of Hera, is marriage. On $\tau \varepsilon \dot{\lambda}$ ○५ and Hera, also as teleia, see Burkert (1985) 133 and Nagy (2013a) 375 .

71 On the interplay between noos and nostos, see above n. 26. The new papyrus P. CG inv. 105 fr. 2 col. i.11-12 supplies, in addition to the scraps provided by P. Oxy. 1231 fr. 1, two words related to noos for the so-called Priamel-song regarding the lacunose transition

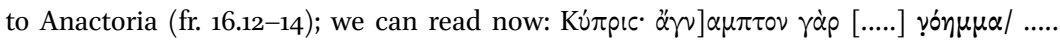

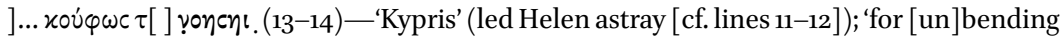
... mind/ lightly ... thinks'. The lines provide the reason: Aphrodite affects the noos and makes it bend (cf. $\gamma v \alpha \dot{\alpha} \mu \tau \tau \omega)$ around and focus on an object of desire. See Burris, Fish, and Obbink (2014) 9, 16-17; West (2014) 2-3. In this case we have the opposite movement: noos is not only responsible for nostos, the return to life from love, but also for falling in love or directing the attention to eros. Burris and Fish (2014) refer the marginal annotation

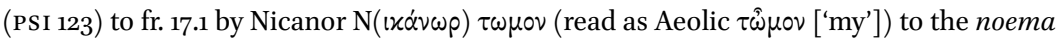
in the preceding column. Thus the lines may not describe Helen's passion but the passion of the singing and fictional 'I', Sappho. In the same manner as she analyzes her own erotic desire and suffering in the new Kypris Fragment, lines 10-12 in terms of rational consciousness, she describes here again the effect of love on her own mind, i.e. the ability of Aphrodite to turn her mind around and cast her waywardly in the realms of eros similar to death. On Sappho fr. 16, see Bierl (2003) (with detailed documentation of the opinions and the history of its interpretation). Despite the great length that can be reconstructed on the basis of the new material and West's ([2014] 2-3) separation of the second part to a new fr. 16 a after line 20, which many critics regarded as the end of fr. 16 before, there is no 'final proof of that' (West [2014] 2). 
After this strong gesture of detachment Sappho gently subordinates herself again. She tells him what he may do: send her out and command (9) her to pray over and over again to Queen Hera. The uncle should employ his power to send Sappho as an intermediary to Hera since she has a special relation with the gods, particularly with Hera, the goddess of marriage, $\ddot{\omega}_{\rho} \alpha$ (seasonality and beauty) and $\tau \dot{\varepsilon} \lambda$ ○s (fulfillment, goal, marriage), ${ }^{72}$ the predominant goddess in the polytheistic system at Mytilene in Lesbos and at Messon. Sappho pleads for the chance to be sent $(\pi \varepsilon \dot{\varepsilon} \mu \eta \eta \nu, 9)$ in an official procession $(\pi \circ \mu \pi \eta \dot{ })$ with her group of girls to Messon to summon Hera in a hymnic and choral prayer. She should do this $\pi \dot{0} \lambda \lambda \alpha$ (10), in an intense and repeated way. What follows is the anticipated ritual speech-act of praying. In direct speech the contents would stand in the optative, but as a prudent and submissive woman she projects her female utterance with infinitives: Charaxos should come back to this place ( $\left.\tau u^{i} \delta \varepsilon, 11\right)$. The deixis is striking and we have two options in understanding it:

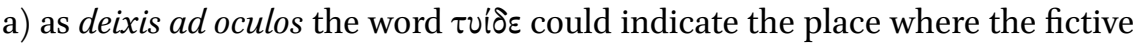
conversation momentarily takes place in the present (probably Messon); or b) as deixis ad phantasma pointing the way to an imagined place designated as 'here' (perhaps the house of Sappho's family) since the audience knows the

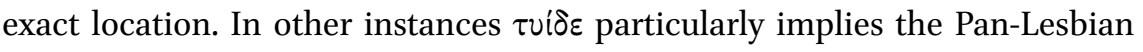
precinct Messon and the choral performance at this holy place dedicated to Zeus, Hera, and Dionysus. ${ }^{73}$ The lyric 'I' should pray to Hera-Sappho and her female chorus in particular address this female goddess-to make Charaxos return from the realm of death, Egypt, and pilot his ship safely to Lesbos. The

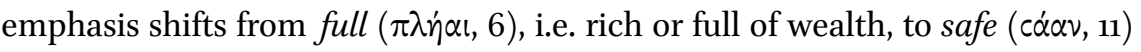
since wealth has no relevance in a religious perspective but safety does. In her continued prayer, Sappho stresses that Charaxos may 'find us safe and sound' as well (13). The 'we' could include the uncle, the entire family at Mytilene or the projected group at Messon.

The group the 'we-form' designates, now obviously including her uncle, says: 'let us entrust all other things to the gods' (13-14) - meaning we can only pray,

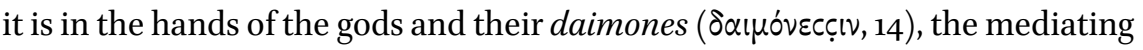
spirits, who help us out from the realms of death. ${ }^{74}$ At this point a traditional

\footnotetext{
72 On Hera and the linguistically related $\omega \rho \alpha$, see Nagy (2013a) 32-33; Burkert (1985) 131 associates 'season' with 'ripe for marriage'; on $\tau \dot{\varepsilon} \lambda$ ○ and Hera, see Nagy (2013a) 44, 375 .

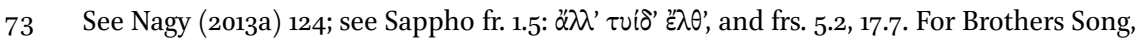
line 11, see frs. 1.5, 5.2, 17.7 and Nagy in this volume.

74 On daimones as opposed to theoi, see Burkert (1985) 179-181, esp. 180: 'Daimon does not designate a specific class of divine beings, but a peculiar mode of activity.' For Nagy (2013a) 109 daimon means 'superhuman force'.
} 
gnome, a piece of wisdom, ensues: 'out of big storms suddenly comes fair weather' (15-16). The metaphoric context of the gnome coincides here with the real situation: seafaring and storms. Salvation comes quickly $(\alpha \hat{i} \psi \alpha, 16)$, or unexpectedly: Zeus is responsible for the weather, and brings about change (metabole).

In the fourth transmitted stanza we have a second gnome on the human level; it follows in a generalized relative clause with the iterative form in the subjunctive conveying a common law: 'of whomever Zeus, the King of Olympus, wishes a daimon, a mediating spirit, as helper to achieve a turn for them from troubles' - ponoi, toils, constitute the quintessential status of mankind- 'those become $\mu \alpha \dot{\alpha} x \alpha \rho \varepsilon c$ and $\pi 0 \lambda \dot{0} 0 \lambda \beta 0 \mathrm{l}$ in a metabole' $(17-20)$. Decisive is thus the will of Zeus to initiate the specific activity of the daimones to bring someone back to life. To some extent this reminds of the Dios boule in the Iliad (1.5). ${ }^{75}$ Moreover, from the female perspective of the pious chorus these persons become blissed, initiated and happy, though perhaps only as dead and immortalized heroes. In the uncle's secular and capitalistic perspective, however, this could mean 'happy and very rich', echoing the conditions under which he hopes Charaxos will return.

Then, in the last stanza, Sappho no longer insists too much on Charaxos: it is in the hands of the gods to make Charaxos return, while we, so the group says, have other options. After all Charaxos' younger brother Larichos could function as a stand-in for Charaxos. If Larichos activated his mind, raising his head to leave his erotic entanglements behind, and became a real man, we would swiftly $(\alpha i \psi \alpha, 24)$ be released from our anguish and sorrow. The metabole of mood can thus be achieved through a more realistic step in the here and now. In an indirect way Sappho pleads for Larichos as the new male leader of the hetaireia, making a claim perhaps for her close family to hold power over the clan, questioning her uncle's claim on her territory of discourse. However even Larichos, as argued above, seems not to be a real option, since the song revolves around love as the quintessential characteristic of Sappho's family. At any rate, lysis (see $\lambda \dot{0} \theta \varepsilon \varepsilon \mu \varepsilon v, 24$ ) and metabole are features of Dionysus, ${ }^{76}$ the third god in the Lesbian triad at Messon, who now seems somehow eclipsedperhaps due to his wild, uncivilized side. However, through these features and the mystic aspect, he comes again to the fore.

75 See also Hom. Il. 12.236, 12.241, 13.524, 20.15, 20.20, and Latacz, Nünlist, and Stoevesandt (2000) 20 ad 1.5.

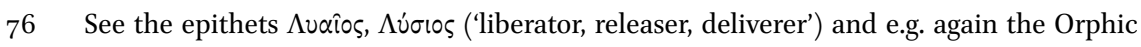
gold-leaves frs. 485.2 (with the parallel passages and explanations), 486.2 Bernabé. 
As far as the performance mode and the occasion are concerned, most critics believe the song is monodic, sung in the family environment. But I claim that a choral performance also is very likely. The original occasion might be either a) in the Sapphic circle, for the purpose of paideia, anticipating the prayer performed for a single, specific occasion, perhaps at Messon; or b) the choral performance that actually took place at the seasonal festival at Messon, performed either once or annually reperformed, a complement to the male assemblies. By singing this song revolving around love, the women might strive to become even more beautiful for the Kallisteia. All things considered, I strongly believe a choral performance at Messon to be the most likely original performance context. But I can also imagine solo reperformances, either by Sappho herself or other persons, in more private settings, such as within her circle or at symposia. According to these differing scenarios passages addressing a 'we' (lines 13 and 21) could be understood differently: in the original performance perhaps as the collective group, in the reperformance apparently as the plural of the 'I' and 'you'.

\section{The Aesthetic and Poetic Dimension of the Brothers Song}

Form and content complement each other and constantly interact. The movement, the flux of ideas, supported by mirroring, parallelism, marked repetitions, chiasms, enjambments and gliding transitions, proceeds smoothly and produces an atmosphere of cultic fusion in choreia. In the Brothers Song everything, viewed through cultic lenses, has a mystic charge. We have underlined that the metaphoric context of the tenor, the gnomic wisdom, coincides with the elements of the mythopoetic and fictionalized story itself. Moreover the fusion of form, content, and metaphor is projected onto a higher level, the entire story becoming an allegory for life, a myth framed by the ritual occasion of the performance. To some extent, Sappho composes her songs on the basis of the daily experience of her female and cultic life, transforming it into higher utterances that eclipse their secular everyday meaning. The mythic and cultic embedding and transformation are essential for the poetic essence.

Moreover, Sappho incorporates other discourses: 1) prayer and cultic language; 2) mystic language and mystery experience; 3) the epic subgenre of nostos; 4) songs of love and lament; 5) songs communalizing erotic experience; 6 ) traditional gnomic wisdom and choral lyric; 7) heroic discourses; and last but not least, 8) the Homeric tradition, alluding to Odysseus, Telemachus, Menelaus, and Penelope. 


\section{Conclusion}

To summarize, the new Brothers Song is not a personal, biographical, and intimate expression of family matters but functions rather within a public dimension. As an originally public and choral performance it communalizes erotic experiences and acts out discourses of power relations in the polis and the clan. As an aesthetic production it is embedded in an overarching songand-performance culture. The Brothers Song is connected with the traditional idea of a myth-and-ritual scenario, creating new myths and narratives for ritual performance. Thus the original occasion for this song was most likely the choral performance during the public festival at Messon. The speech-act of $\pi \dot{0} \lambda \lambda \alpha$ $\lambda_{i \text { iccec } \theta \alpha \mathrm{l}}(10)$, the intense prayer, is the song. It aims to make the impossible possible and to initiate change, metabolai. Life consists of ponoi, strains, and despondencies: only through poetry, song, and performance do the performers as well as the audience achieve the necessary change. Through a series of communalized cases in a 'biographical' narrative of family and songs about unrequited love in the female group, different audiences can reflect upon their own life experience. Through cultic charging and the embedded discourses of mystery, salvation, and happiness, the performers as well as the audience are elevated to a higher existence. From distress and anguish, we grasp happiness and fulfillment.

The Brothers Song does not really offer an alternative but, like the new Kypris Song and many other erotic poems, it deals with the consequences of love. Sappho thus portrays erotic entanglement as a programmatic feature of her clan. She probably used the bio-mythic cycle with her brother as well as more direct exchanges about love for wider educational and political purposes. As seen, the erotic song becomes an aristocratic and female discourse; politics with other means of addressing the strife of the hetaireiai in Lesbos.

The song, at last, contains such a generalized poetic potential that it easily transcended the limitations of the primary context and warranted reperformance in new settings, such as the male symposium. Through a diachronic process, it could even be exported and transferred to new locations, like the new cultural center at Athens, where the symposium and festive contexts like the Panathenaia continued the ongoing chain of reperformances. 